\title{
HIV status among women with mental illness
}

\author{
T Jeyaseelan Senthinath ${ }^{*}$, T Senthilkumar ${ }^{2}$, P Revathi ${ }^{3}$ \\ From International Conference on Prevention \& Infection Control (ICPIC 2011) \\ Geneva, Switzerland. 29 June - 2 July 2011
}

\section{Introduction / objectives}

Mentally ill women (MIW) are sexually exploited. Despite, their HIV Status is less studied. Present report aims to study the HIV status of MIW and highlight the difficulties encountered while handling them.

\section{Methods}

HIV status was screened by standard methods recommended by National AIDS Control Organization, INDIA for 50 young women with various mental illnesses. Difficulties encountered while handling them were elicited with the help of care takers. The data were analysed by simple descriptive statistics.

\section{Results}

The age of the subjects varied from 19 - 34, with the median 25 yrs. They were wandering on the road \& were sexually exploited for their basic needs. Cheap \& easy availability, sexual perversion, substance abuse, Lack of family support, inability to stress condom usage to partners leads to dissemination of HIV in the society. HIV was positive (64\%) among them \& CD4 count was low as much as $14 \%$. Highly Active Anti-Retroviral Therapy (HAART) could not be initiated due to nonacceptance, non-cooperation, running away from shelter/ rehabilitation home, non-compliance of drug intake, $\&$ issues related to underlying disease. They were neither aware of condom nor did they practice any protective measure.

\section{Conclusion}

As handling MIW has multiple problems there is a need for 1 to 1 counselling to protect them, which will prevent the spread of HIV and initiate HAART therapy for them. The authorities and the public should be made

${ }^{1}$ Microbiology, Chennai Medical College Hospital \& Research Centre, Trichy, India

Full list of author information is available at the end of the article aware of this mode of dissemination of HIV and measures should be taken to prevent them.

\section{Disclosure of interest}

None declared.

\section{Author details}

${ }^{1}$ Microbiology, Chennai Medical College Hospital \& Research Centre, Trichy, India. ${ }^{2}$ Anbalaya, Trichy, India. ${ }^{3}$ Pharmacology, Chennai Medical College Hospital \& Research Centre, Trichy, India.

Published: 29 June 2011

doi:10.1186/1753-6561-5-S6-P328

Cite this article as: Jeyaseelan Senthinath et al.: HIV status among women with mental illness. BMC Proceedings 2011 5(Suppl 6):P328.

Submit your next manuscript to BioMed Central and take full advantage of:

- Convenient online submission

- Thorough peer review

- No space constraints or color figure charges

- Immediate publication on acceptance

- Inclusion in PubMed, CAS, Scopus and Google Scholar

- Research which is freely available for redistribution

Submit your manuscript at www.biomedcentral.com/submit
() Biomed Central

\section{() Biomed Central}

(C) 2011 Jeyaseelan Senthinath et al; licensee BioMed Central Ltd. This is an open access article distributed under the terms of the Creative Commons Attribution License (http://creativecommons.org/licenses/by/2.0), which permits unrestricted use, distribution, and reproduction in any medium, provided the original work is properly cited. 